\title{
Comunicación, discursos y contestación política en la Castilla tardomedieval
}

Nuria Corral Sánchez

Universidad de Salamanca

\author{
Communication, discourses and \\ political response in late medieval Castile
}

Este trabajo ha sido realizado en el marco de una ayuda de Formación de Profesorado Universitario (FPUi4/or88I), Ministerio de Educación, así como del proyecto Ciudad y nobleza en el tránsito a la Modernidad: autoritarismo regio, pactismo y conflictividad política. Castilla, de Isabel I a las Comunidades (ref. HAR2017-83542-P), Ministerio de Economía, Industria y Competitividad/Agencia Estatal de Investigación/Fondo Europeo de Desarrollo Regional.

RECIBIDO: IO-02-202O

EVALUADO Y ACEPTADO: 24-08-2020

Territorio, Sociedad y Poder, No I5, 2020 [PP. 47-65] 
Resumen: Desde una perspectiva cultural, el estudio del discurso resulta fundamental para el análisis de los conflictos sociopolíticos. Con el objetivo de concienciar a la comunidad y ganar su favor, los actores políticos desarrollan diversas estrategias discursivas en un complejo proceso de comunicación donde la palabra adquiere varios registros. En el presente artículo reflexionaremos acerca de estas cuestiones teóricas, precisando su utili-

Abstract: Discourse studies are essential to analyse sociopolitical conflicts from a cultural perspective. Thus, political actors develop varied discursive strategies in order to raise awareness within the community and win its favour, in a complex communication process where words acquire different registers. In this paper we will reflect on these theoretical issues, specifying their utility for the investiga- dad para las investigaciones sobre culturas y relaciones políticas en la Edad Media. Presentaremos además una propuesta metodológica para el estudio de la contestación política en el siglo $\mathrm{xv}$, especialmente a partir de fuentes cronísticas y literarias.

Palabras clave: Metodología, historiografía, discurso, Castilla, siglo Xv

tion of political cultures and relations in the Middle Ages. Furthermore, we will present a methodological proposal to study political response in the $15^{\text {th }}$ century, specially from chronistic and literary sources.

Keywords: Methodology, historiography, discourse, Castile, $15^{\text {th }}$ century. 
1. INTRODUCCIÓN: ¿POR QUÉ EL LENGUAJE IMPORTA?

En su obra Hablar y callar, Peter Burke (1996: 38) resaltaba el poder de la lengua en los estudios históricos y, como ejemplo de su fuerza, mencionaba el insulto, una forma de agresión, una palabra para atacar. Al abordar las relaciones sociopolíticas en Roma durante el siglo XVII, sostenía que algunas de estas caracterizaciones no tenían mucho que ver con el comportamiento real de los insultados, pero eran el mejor medio para destruir su reputación en la sociedad ${ }^{1}$. En la línea de estas observaciones, cada vez son más numerosos los trabajos que abordan las cuestiones discursivas en el marco de distintas épocas históricas, como la contemporánea, pero, evidentemente, también la medieval.

Con este trabajo pretendemos diseñar un marco teórico para el análisis discursivo de las fuentes narrativas bajomedievales - en concreto, nos ceñiremos a la cronística y la literatura-, a partir de la síntesis y reflexión en torno a las diversas aportaciones realizadas desde la sociolingüística y ciertos trabajos históricos. Comenzaremos con una introducción conceptual de breve recorrido por los Estudios del Discurso (ED) y su conexión con la Historia mediante la perspectiva

\footnotetext{
${ }^{1}$ Burke defiende la historia social del lenguaje, un enfoque más sociológico que el de Koselleck y Pollock y más concreto que Habermas, aunando lingüística, sociología e historia. Recientemente se ha publicado un interesante trabajo respecto al uso de las injurias en la Edad Moderna desde una perspectiva que aúna historia del léxico e historia social (Tabernero, Usunáriz, 20I9).
}

cultural, con énfasis en las contribuciones del medievalismo. Después, trazaremos algunas de las líneas de investigación que han abordado la Castilla bajomedieval a partir de estos puntos de vista, evidenciando el largo recorrido historiográfico en esta disciplina de los trabajos sobre la comunicación para el estudio de procesos políticos como la propaganda o la protesta. Por último, planteamos una propuesta de aplicación de las nociones comentadas como enfoques a partir de los que analizar las fuentes literarias y cronísticas bajomedievales.

\section{SOCIEDAD Y DISCURSO: HACIA UNA HISTORIA DE LAS CULTURAS POLÍTICAS}

Las primeras contribuciones de los estudios del discurso se orientaron hacia el lenguaje y la comunicación desde perspectivas fundamentalmente estructuralistas. No sería hasta los años sesenta y setenta, con el «giro lingüístico» y de la mano de la aparición de la pragmática, la sociolingüística o la psicolingüística —entre otras disciplinas-, cuando se profundizara en la importancia de los contextos sociales y culturales. A partir de entonces también se modificó la consideración tradicional de la comunicación como un proceso de conducción o circulación de mensajes ${ }^{2}$. Esta concepción pasó a ser

\footnotetext{
${ }^{2}$ Debido a las limitaciones de extensión de este trabajo y a los objetivos planteados, realizamos aquí un somero repaso, a sabiendas de que podrían incluirse numerosos matices en esta evolución teórica.
} 
vista como simplista y superficial, ya que obviaba la capacidad de construir, reproducir y modificar significados mediante el lenguaje (Van Dijk, 20I2: 26-27). En este sentido, abordar la comunicación en tanto que discurso favorecería la superación de la forma de entender el lenguaje únicamente como un canal de transmisión. El discurso se convertía así en una construcción y una herramienta utilizada por agentes y actores sociales ${ }^{3}$.

Paralelamente a estos cambios, se multiplicaron desde distintos ámbitos los estudios sobre cuestiones próximas al discurso, como la ideología, la opinión pública, la propaganda o la legitimación, con autores de la talla de Habermas (1997) o Foucault (1983). Este último autor, que reivindicaba la importancia del discurso como medio — y causa — de lucha política, haría énfasis especialmente en su exterioridad y en sus mecanismos de control, ya que mediatizan el poder que conlleva el discurso - y, en última instancia, sus efectos-.

A finales de los setenta comenzaron a desarrollarse investigaciones con una carga sociopolítica más fuerte —la «lingüística crítica»—, que en las décadas siguientes desembocaron en el Análisis Crítico del Discurso (ACD) o también Estudios Críticos del Discurso (ECD) (Van Dijk, 20I2: 27-28). El grupo fundacional de esta corriente, liderado por Roger Fowler (1983), junto a Hodge, Kress, Trew y otros, puso el foco en el control del discurso ejercido por quienes tienen un acceso privilegiado al poder.

Desde entonces, se ha mostrado interés por la reproducción discursiva del poder (Fairclough, 1995), el estudio crítico del discurso político (Chilton, 2004), la ideología o diversos problemas sociales (Van Dijk, 2003). En definitiva, los ECD se centran en los sistemas del texto que dependen de condiciones sociales, que varían en función de estas o que conllevan con-

\footnotetext{
${ }^{3}$ La pragmática nos interesa en tanto en cuanto se dedica al análisis de las funciones de los enunciados lingüísticos, así como de sus características en los procesos comunicativos. Una de las primeras aportaciones importantes de la pragmática fue la teoría de los actos de habla, desarrollada por John Austin (1982) en una serie de conferencias en la Universidad de Harvard durante los años cincuenta. Suya es una clasificación elemental que se ha ido complejizando con el tiempo, la de los actos locutivo, ilocutivo y perlocutivo. Como acercamiento a esta y a otras teorías, resulta interesante la obra de Covadonga López Alonso (20I4).
}

secuencias concretas en la sociedad. Es decir, lo importante es la relación entre sociedad y discurso, no el contenido en sí mismo. La teoría del discurso debería, por tanto, servir de puente entre el «micronivel del orden social», al que pertenecen los discursos y otras interacciones, y el «macronivel» de las instituciones, los grupos y el poder (Van Dijk, 2009: 22-24, I49).

Como puede suponerse, se trata de un ámbito muy heterogéneo, pero hay que hacer énfasis en que estos estudios no deben ser entendidos como un método de análisis —ya que utilizan cualquier método pertinente en función de sus objetivos-, sino como una esfera académica multidisciplinar entre humanidades y ciencias sociales, es decir, una perspectiva de teorización, el punto de vista que tomamos en este artículo. Las reflexiones de estos autores sobre los procesos discursivos y su vinculación con las relaciones sociopolíticas se revelan de gran utilidad para el estudio de sociedades como, en este caso, la medieval. En este sentido, se trata de observar una parte de las relaciones políticas y sociales desde los discursos y de los procesos cognitivos que desencadenan.

A partir de la evolución teórica y los autores citados en las páginas anteriores, consideramos el discurso un proceso comunicativo completo, no solo como una expresión verbal, sino también, y sobre todo, como una interacción y una práctica social contextualizada, es decir, como un acontecimiento en una situación social, cultural, histórica y política concreta (Van Dijk, 2009: 22). Pese a que el análisis de la gramática y del contenido se centra únicamente en los enunciados, los estudios del discurso tratan de ir más allá. Por tanto, en el concepto de discurso habría que tener en cuenta:

No sólo elementos observables verbales y no verbales, o interacciones sociales y actos de habla, sino también las representaciones cognitivas y estrategias involucradas durante la producción o comprensión del discurso (...). Nos interesa observar el discurso como un factor dinámico de nuestras interacciones sociales, pero dicho dinamismo no implica una falta de 
esquematización o normas identificables en él, y que nos permitan encontrar modelos para su interpretación y análisis (Meersohn, 2005: 29I).

En resumen, se puede subrayar que a través del discurso no solo se transmiten ideas, sino que se puede influir en la sociedad y ejercer el poder. La relación del discurso con estos dos elementos, sociedad y poder, se expresa en diversos procesos y nociones cognitivos, entre los que debemos destacar algunos como representaciones-construcciones cognitivas, ideología, identidad, legitimación y propaganda, dado que los aplicaremos a partir de fuentes bajomedievales en el último apartado de este trabajo ${ }^{4}$.

Estos conceptos, así como el de discurso, se suelen englobar en los estudios históricos sobre cultura política. Frente a la definición tradicional de esta como sistema comprensivo de valores, creencias y actitudes en relación con el sistema político imperante, en los últimos años se defiende - por influencia de la antropología y ciertas corrientes interpretativistas-, otra basada en un sistema de significados, símbolos, rituales, lenguajes, mitos y visiones. Se ha venido recuperando también el sujeto como protagonista que fija los objetivos y utiliza los recursos proporcionados por la cultura. Se trataría de perfilar los marcos culturales y los significados que los actores políticos otorgan a la realidad política y a sus objetivos 5 . Bajo la influencia del giro lingüístico y de las innovaciones en historia y sociología, algunos han incluido en la noción de cultura política «representaciones simbólicas de la sociedad, las identidades colectivas y los discursos que las forjan", además de diversas aspiraciones y formas de sociabilidad compartidas. La insatisfacción con algunas posturas materialistas ciertamente deterministas llevó

\footnotetext{
${ }^{4}$ Sobre la importancia de los discursos en los estudios sociales, remitimos a Bourdieu (1987).

5 Al mismo tiempo, se tiende a subrayar la importancia de las subculturas, concebidas como distintas actitudes que varían en función de los sectores sociales, es decir, de la estructura social y cultural. Estas subculturas se basan en la aceptación del sistema político (difieren en ciertos aspectos, pero aceptan el sistema) o en su rechazo. En última instancia, las culturas políticas estarían formadas por los rasgos predominantes compartidos por sus propias subculturas (Cabrera Acosta, 20IO: 3I).
}

a sectores de la Nueva Historia Cultural (NHC) a considerar la intermediación de la cultura de manera que la conjunción de la situación social y ciertos dispositivos culturales — tradiciones, experiencias— desembocaría en la conciencia política:

Para que el ser social devenga agente [político] es necesario que se convierta en ser consciente. Desde este punto de vista, los sujetos políticos están ya dados en la estructura social — como ocurre, por ejemplo, con las clases-, pero se constituyen como tales en la esfera cultural (Cabrera Acosta, 20I0: 54-60).

Se observa así una interacción mutua de lo social y lo cultural en el comportamiento político, que influiría en el desarrollo de la Nueva Historia Política (NHP). Los elementos culturales participan en la formación de intenciones, objetivos políticos, no como una correa de transmisión de la estructura social, sino como un conjunto de recursos que son utilizados por los actores políticos de forma consciente. En las definiciones que se dan en el ámbito de la historia cultural, también se tiene en cuenta como «conjunto de discursos o prácticas simbólicas», posiciones ideológicas, conjuntos de significados y esfera de categorías que posibilita que funcionen ideas, intereses, identidades y estrategias de acción (Cabrera Acosta, 20I0: 70) .

Las aportaciones que se han consagrado desde la historia medieval al estudio de las culturas políticas son tan numerosas y de tanto calado que escapan a cualquier estado de la cuestión sucinto que podamos plantear aquí, incluso aunque nos ciñéramos exclusivamente al periodo bajomedieval. En lugar de hacer un registro pormenorizado, que excedería los objetivos y límites espaciales del artículo, atenderemos a continuación a algunas líneas historiográficas que se han desarrollado.

\footnotetext{
${ }^{6}$ Asimismo, encontramos la concepción de cultura política como discurso, algo más ambigua, que se sustenta en dos principios esenciales. Por un lado, la consideración del lenguaje como instrumento para expresar ideas y diseñar ese modelo cultural, sus estrategias e intereses y, por otro, la supeditación de los sujetos a este bagaje común (Cabrera Acosta, 20Io: 67).
} 
En paralelo al acercamiento de la NHP y la NHC, se está prestando una mayor atención a la sociedad política tardomedieval y a su vertiente cultural. Jean-Philippe Genet ha teorizado en varias ocasiones sobre este asunto. Este autor sostiene que el estudio de la sociedad política debe enfocarse desde distintos ángulos, a saber, su composición — los hombres del poder, quienes dependen de ellos y las cámaras representativas-, su organización vertical — con partidos aristocráticos (bandos, clientelas, afinidades) que se definen en relación con el poder del rey-y el aspecto cultural signos, palabras, imágenes, sonidos, desplazamientos que tienen sentido en el espacio público-:

Para que haya un funcionamiento político, la sociedad debe poder debatir sobre los tipos de poder y manifestar su adhesión - o rechazo - a la forma en que el soberano lleva los asuntos. [...] es necesario una comunicación permanente entre los diferentes miembros de la sociedad política, con el fin de que los mensajes se transmitan, se decodifiquen, se confronten, se ajusten (Genet, 2009: 27).

El sistema de comunicación forma parte de toda sociedad política, de ahí, para Genet, la relevancia de su estudio en estos momentos de génesis del Estado moderno. Para él, el sistema comunicativo estaría dominado por las élites del saber y de poder, mientras que otros, como Claude Gauvard (2007: 17), han preferido destacar las interacciones entre política y pueblo, englobando élites y grupos populares, con el objetivo de no oponer formas de cultura a menudo mezcladas y complementarias. Los últimos años han visto la aparición de diversos trabajos sobre comunicación y lenguajes políticos, tanto desde un espectro general, como sobre lugares concretos (Mairey, 2009; Gamberini, Genet, Zorzi, 20II; Challet, 20I2; Dumolyn, 20I2).

Desde esta perspectiva centrada en la comunicación y el lenguaje, ha ido profundizándose en cuestiones como la propaganda, los procesos de legitimación o la opinión —y esfera— pública. Según Genet (2007: 89IIo), los lenguajes de la propaganda operan en el sistema de comunicación con un destinatario genérico, la sociedad política, a cuyos miembros se intenta convencer usando los recursos ofrecidos por la esfera pública. Como afirma Van Dijk (2009: 36), «el control del discurso público implica el control de la mente del público $y$, por consiguiente, indirectamente, el control de lo que el público quiere y hace». El espacio público viene siendo también objeto de estudio en el medievalismo europeo, como lo demuestran obras como la dirigida por Boucheron y Offenstadt (20II), recogiendo aportaciones surgidas en torno a la obra de Habermas. Por otro lado, Barbara Rosenwein (2006) ha elaborado el concepto de "comunidades emocionales», defendiendo el estudio del control social y el orden público para comprender por qué y cómo el Estado necesitó apoyarse en la opinión pública para su desarrollo.

\section{COMUNICACIÓN POLÍTICA Y CONFLICTO EN CASTILLA: REPASO HISTORIOGRÁFICO}

La importancia del lenguaje para los estudios históricos también ha sido reivindicada por algunos autores que se ocupan de la Castilla bajomedieval. En este sentido, Nieto Soria considera la retórica como un instrumento fundamental de la lucha política, sobre todo a partir de la legitimación y la deslegitimación a través de diversos medios — sermones, poesías, predicaciones...-. Según este autor, la utilización de conceptos políticos generales en enfrentamientos políticos concretos permite observar la imbricación de la necesidad política y la producción intelectual (Nieto Soria, 2004: 708-710).

Por el contrario, ciertas cuestiones relacionadas con

\footnotetext{
${ }^{7}$ Historiadores especializados en otros periodos también han subrayado la necesidad de ampliar el ámbito de la historiografía hacia nuevos campos, como Celso Almuiña, para quien:

El estudio de la opinión pública en sí misma (intrahistoria) y como sujeto agente del quehacer histórico está prácticamente por hacer. No se puede confundir historia de los medios (instrumentos) con historia de las opiniones públicas (cómo se forman) [...] Desde luego, ésta, como motor de la evolución histórica, no puede ser olímpicamente desconocida, como lo ha sido hasta el presente. Hay que incorporarla a la reconstrucción del conocimiento histórico (Almuiña Fernández, 2007: 7).
} 
los discursos y que hemos tratado anteriormente sí han logrado un mayor interés por parte de los historiadores. Así, por ejemplo, encontramos trabajos que enlazan discurso con legitimación, ideología, identidad o esfera pública y a los que nos iremos refiriendo en este apartado. Oliva Herrer (20II: 369) ha defendido la existencia, en el marco de la efervescencia conflictiva del siglo $\mathrm{xv}$, de un amplio proceso de comunicación política desplegado desde altas instancias del poder. Las «culturas políticas» hispánicas, categoría que engloba estas mismas nociones, se consagraron como objeto historiográfico hace ya más de tres décadas, inspirando obras colectivas como la dirigida por Rucquoi (1988), aunque parece haberse revigorizado en los últimos diez años (Oliva Herrer, Challet, Dumolyn, 20I4; Jara Fuente, 2017). Sin embargo, este tema ha sido abordado frecuentemente poniendo el foco de análisis en alguna de las tres principales instancias políticas castellanas: monarquía, nobleza y ciudad.

Comenzando por la primera de ellas, el mismo Nieto Soria (1988, 1999, 2007), siguiendo el camino abierto por autores anteriores como Kantorowicz o Gimeno Casalduero, se ha convertido en una referencia obligatoria a la hora de estudiar la imagen regia y los fundamentos legitimadores de su poder. Los estudios de esta temática han proliferado desde entonces bajo la firma de distintos medievalistas de renombre (Valdeón, 1992; Monsalvo Antón, 2019a). Entre ellos, habría que destacar acercamientos metodológicos como los de Carrasco Manchado (1998; 2006; 2007) o Foronda (2013), quienes han defendido la importancia del léxico y la lexicometría para las investigaciones históricas. Por cercanía a la institución regia, también habría que tener en cuenta los estudios de este último autor sobre los privados castellanos y la construcción de su imagen (Foronda, 2004).

Los estudios sobre la ideología nobiliaria en la baja Edad Media han estado quizá menos extendidos, pues la bibliografía sobre este grupo suele abundar más en los aspectos políticos y socioeconómicos. Quintanilla Raso (2005) y Beceiro Pita (2000), dos buenas conocedoras de la nobleza bajomedieval, han dedicado algunos trabajos a estas cuestiones. Ambas conciben las manifestaciones representativas, propagandísticas y discursivas de la nobleza como elementos clave en su legitimación social y, sobre todo, política. En los últimos años han aparecido diversos trabajos que profundizan en las imágenes y valores nobiliarios, pero sólo nos detendremos en algunos. Por un lado, Franco Silva (20I2) ha continuado el estudio de los discursos de los nobles, reconociendo en el siglo xv la existencia de un programa político que pretendía legitimar su participación en el poder de forma conjunta con el rey. Con relación a este grupo social y a sus fundamentos legitimadores, no debemos pasar por alto obras vinculadas al ideario caballeresco (Dacosta, 2016). Por otro lado, autores como Gibello Bravo (1999) se han centrado en el discurso bajomedieval sobre la nobleza castellana, que en buena medida también era creado por sus propios miembros.

Por último, la cultura política urbana ha recibido la atención de varios historiadores en los últimos años y a ella se han consagrado numerosas publicaciones, como la editada el pasado ańo por Monsalvo Antón (20I9b). Autores como Jara Fuente (20I3a) y Asenjo González (1999) han tratado de sintetizar los intentos de las ciudades castellanas por legitimar su papel político en la transición secular, el primero haciendo énfasis en la propia construcción de la identidad urbana y la segunda, en la relación existente entre la propaganda cívica y la monárquica.

Como vemos, casi siempre se ha estudiado el imaginario y el discurso de forma amplia y, cuando se orientan hacia su utilización política, el foco suele ponerse sobre el ámbito propagandístico, con la excepción de algunos trabajos sobre la reprobación del rey (Nieto Soria, 2005). Los discursos de contestación política suelen observarse como una parte puntual de los fundamentos ideológicos de la legitimación y la participación políticas ${ }^{8}$. Este aspecto ha sido abordado sobre todo en el caso de las ciudades, cuyos discursos

\footnotetext{
${ }^{8}$ La crítica muchas veces aparece como un registro negativo de la propaganda o como contrapropaganda: un actor político ataca al contrario para legitimarse a sí mismo. Si seguimos la definición de propaganda política propuesta por Carrasco Manchado (1998: 23I), no sería descabellado ver en la crítica bajomedieval un componente de aquella.
} 
políticos suelen enmarcarse en una dialéctica que las enfrentaría con la nobleza (Jara Fuente, 2013b). La realización de varios congresos dedicados a discursos de conflicto y protesta política demuestra la relevancia de estas cuestiones'. Asimismo, podemos encontrar varios trabajos recientes que subrayan las peticiones políticas de pecheros y campesinos, a veces en un marco de conflicto con caballeros y señores (Monsalvo Antón, 20II; Oliva Herrer, 20II). En este sentido, existe un gran número de estudios sobre los conflictos bajomedievales en la península Ibérica, destacando la obra de Valdeón (I983) y otros trabajos posteriores que están aportando nuevas perspectivas al tema ${ }^{10}$.

Hecho este repaso, puede concluirse que las culturas políticas de la Castilla bajomedieval están siendo actualmente objeto de una atención significativa por parte de los medievalistas, de manera vinculada casi siempre a estudios sobre el ejercicio del poder de los distintos grupos sociopolíticos. Esto ha llevado a muchos a reivindicar el discurso como un compañero de la participación política y de sus instrumentos de acción, conjugando así lo simbólico y lo social. En estos casos, al estudiar, por ejemplo, los conflictos antiseñoriales, la retórica adquiría un lugar secundario en el análisis.

Nos hemos referido hasta ahora a las obras que tratan las representaciones e ideologías políticas de forma general a partir del estudio de una variada tipología de fuentes. No obstante, hay otros trabajos que han abordado dichos temas en el marco de estudios concretos sobre una fuente o un grupo específico de ellas, interesándonos fundamentalmente las narrativas:

\footnotetext{
${ }^{9}$ En septiembre de 2014 se celebró en Valladolid el congreso Formas de protesta, movilización y lucha política en la Baja Edad Media. Después, en 2016 y 2017 tuvieron lugar dos coloquios internacionales en el marco de nuestro grupo de investigación, celebrados en Cuenca y Salamanca, con los títulos, Discurso politico y relaciones de poder: ciudad, nobleza y monarquía en la Baja Edad Media y Elites, conflictos y discursos politicos en las ciudades bajo medievales de la Península Ibérica, respectivamente. Ambos eventos dieron como resultado la publicación del conjunto de estudios presentados, que ya hemos citado anteriormente. Estos estudios están siendo desarrollados también en otros lugares de Europa, como evidencia el congreso Langages politiques populaires à la fin du Moyen Âge. Reprise, réappropriation, création, celebrado en mayo de 2015 en Italia

${ }^{10}$ Por cuestiones de espacio, remitimos a la aproximación historiográfica realizada por Córdoba de la Llave (2014) hace algunos ańos y a la reciente monografía publicada después por Monsalvo Antón (2016).
}

crónicas y literatura. Tal relación no pretende ser exhaustiva, sino indicativa de algunos de los trabajos más destacados y ciertas tendencias interpretativas.

$\mathrm{Al}$ analizar la bibliografía con retrospectiva observamos un cambio significativo en cuanto al tratamiento de la relación que une la escritura y el poder. La postura historiográfica que tomaba la primera como un mero reflejo de los acontecimientos políticos parece haber sido relegada desde finales de los años ochenta por la aparición de estudios que subrayan los nexos multidireccionales entre narrativa, sociedad y política (Serverat, 1997; Severin 2005). Entre ellos habría que destacar aquellos que abordan los aspectos ideológicos y comunicativos de los textos en la dinámica sociopolítica, de gran relevancia para el estudio que planteamos ${ }^{11}$. Deyermond (1988) ha sido uno de los principales defensores de la importancia de la literatura como canal de expresión de la ideología del Estado moderno, planteamiento que ha repercutido incluso en las colecciones de historia de la literatura recientes, que tienen más en cuenta las cuestiones contextuales e ideológicas. Destaca, en este sentido, el ciclópeo trabajo de Gómez Redondo (1998-2007) sobre la prosa castellana de la Baja Edad Media, donde incluye desde pequeños tratados hasta las grandes crónicas reales. En efecto, la cronística tardomedieval viene siendo abordada cada vez más frecuentemente como un importante medio de acción para las instancias de poder (Montero Málaga, 2013; Villa Prieto, 2015; Barbosa Schiavinato, 2018) ${ }^{12}$. En este sentido, Francisco Bautista (20I5) ha hecho énfasis en las transformaciones del siglo Xv para acentuar la importancia de las crónicas en la propaganda y la legitimación de diversos actores políticos. Tal evolución ha llevado finalmente a considerar la palabra, en general, como un instrumento fundamental en los

\footnotetext{
11 Debido al tema que nos atañe, aquí nos limitaremos a citar aquellos trabajos de índole más histórica, obviando así los muy numerosos estudios que priman cuestiones textuales y compositivas - a veces sobre stemmata realmente complejos-, pues, pese a su enorme validez científica, no suelen incluir observaciones sobre la ideología de la obra o interpretaciones sociopolíticas. Se trata, no obstante, de una recopilación sucinta, ante la imposibilidad de incluir todos los estudios sobre estos temas.

${ }^{12}$ Aunque está enfocada sobre todo al periodo moderno, revierte cierto interés para los siglos bajomedievales la obra de Richard Kagan (2010).
} 
conflictos, cuyo papel ha sido reivindicado por autores como Nieto Soria (2004) y Perea Rodríguez (2007). Estos planteamientos nos han conducido recientemente a estudiar a partir de la cronística las expresiones de oposición a las injerencias de la nobleza en las ciudades castellanas (Corral Sánchez, 2019).

Los discursos de crítica política en las fuentes exclusivamente literarias dieron lugar a la confección del término «literatura de protesta», por lo que vamos a dedicar algunas líneas a este peculiar aspecto. Como es lógico, los cambios de enfoque mencionados más arriba afectaron también a los estudios sobre estas obras «de protesta». Entre los sesenta y los noventa, Rodríguez Puértolas (1968; 1989) publicó dos antologías de poesías cuyo contenido consideraba crítico desde el punto de vista político y moral, acompañándolas de unas notas introductorias y de un breve análisis de cada obra. Adviértase que este autor basaba sus interpretaciones en la contraposición de la nobleza medieval contra la burguesía renacentista, esquema que ha sido matizado en los últimos años (Rucquoi, 2006: 248). Es posible encontrar una mayor contextualización en la monografía que Scholberg (197I) publicó por aquel entonces, una interesante síntesis de la sátira ibérica medieval. Ambos autores realizaron un esfuerzo considerable y muchas de sus indicaciones deben ser tenidas en cuenta. Sin embargo, dadas sus fechas de publicación, la interpretación sociopolítica que incorporan hoy resulta en ocasiones escasa y sería preciso revisar algunas de sus observaciones, ya superadas a la vista de todos los avances producidos desde entonces en la filología y la historia.

La cuestión de la protesta política en la literatura originó un debate en torno a la misma condición de su existencia. Así, Ottavio Di Camillo (I99i) llegó a negar que en la literatura castellana hubiera crítica política a partir del análisis, sobre todo, del Cantar de mio Cid y el Libro de buen amor. Para defender esta idea argumentaba que los autores, en su mayoría nobles, serían favorables a la centralización del poder monárquico y, por tanto, no tendría sentido criticarlo. Por lo que respecta a las diatribas del siglo $\mathrm{xv}$, sostiene que serían simplemente invectivas ad hominem, contra unas personas determinadas. Si bien admite la existencia de ataques a la alta y vieja nobleza por parte de la baja y nueva nobleza, no reconoce en ellos componente político. Otros autores han mantenido esta postura, como Barbero y Estrella, quienes han considerado que las denuncias al grupo nobiliario no eran protesta per se, sino instrumentos al servicio de las luchas entre facciones (Barbero, Estrella, 2006). Esta tesis negacionista parece basarse en la equiparación de la crítica política y la crítica al sistema. Sin embargo, como se ha defendido recientemente, sería necesario separar los dos ámbitos, puesto que la existencia de la primera no conlleva necesariamente la existencia de la segunda (Corral Sánchez, 20I8a). Es decir, la protesta ante las decisiones regias de gobierno puede considerarse crítica política sin necesidad de que se cuestione la monarquía.

Aunque no suele especificarse demasiado el grado o el fondo de la censura, son numerosas las aportaciones que han venido defendiendo la existencia, en determinadas obras cronísticas y literarias, de discursos de crítica política como tal, dirigidos contra distintos sectores sociales, especialmente el noble. Con todo, hasta ahora no se ha dado demasiada importancia al contenido de dichas censuras como objeto de análisis global, sino que, como hemos sugerido ya, han primado los estudios parciales, dedicados a una obra, un autor o un personaje en concreto ${ }^{13}$.

\section{NUEVOS ENFOQUES PARA LA CRONÍSTICA Y LA LITERATURA DEL SIGLO XV}

El estado de la cuestión que acabamos de definir nos permite subrayar la importancia de la palabra como un instrumento más de lucha política, junto a otros como la violencia, el rito o el asociacionismo. Por otro lado, la relevancia de la legitimación —o deslegitimación- mediante determinados conceptos políticos en los enfrentamientos nos permite observar la unión entre necesidad política y producción intelectual desde el

\footnotetext{
${ }^{13}$ Para hacer frente a este vacío, hemos realizado un estudio de carácter general en nuestra tesis doctoral, defendida en diciembre de 2019.
} 
siglo XIII, pero con especial intensidad en las centurias siguientes ${ }^{14}$. Con el objetivo de concienciar - a veces también movilizar - a la comunidad de forma que les fuera favorable, los actores políticos desarrollaban un complejo proceso de comunicación en el que la palabra adquiría varios registros, entre ellos el literario, el cronístico o el jurídico. Nos detendremos en los dos primeros debido a su importancia en la cultura política bajomedieval, como veremos a continuación.

\section{I. LA RIQUEZA DE LAS FUENTES NARRATIVAS}

El diálogo entre las disciplinas humanísticas ha favorecido la revalorización del contexto desde la filología, así como, en contrapartida, de las fuentes literarias desde la historiografía. La pertinencia de estas en la investigación sobre la Edad Media ha sido fuertemente reivindicada en diversos ámbitos. Bouhaïk-Gironès considera una salida ventajista restringir el campo de estudio para evitar acudir a ella, a menudo relegada por el menosprecio de la ficción. Frente a esto, defiende su utilización, especialmente para los estudios de historia cultural — La séparation des sources historiques littéraires se fait au détriment de l'intelligibilité de la société médiévale» (Bouhaïk-Gironès, 2007: 156)—, y recomienda la confrontación de una tipología diversa de fuentes. La validez de la literatura para el estudio de la historia cultural y social está ampliamente aceptada, pero es indiscutible en cuanto al estudio de las posiciones ideológicas que expresan los autores. Este factor, que a menudo se expresa como uno de los inconvenientes intrínsecos al uso de fuentes literarias, resulta fundamental aquí, para el estudio de determinadas posiciones ideológicas.

La forma literaria en la que encontramos más frecuentemente la crítica política durante el siglo xv es la sátira, que se sirve de numerosos géneros, dependiendo, como recuerda Scholberg (I97I: II), de la ac-

\footnotetext{
${ }^{14}$ Es conveniente subrayar la especificidad de estas herramientas, sobre todo si tenemos en cuenta que los actores del periodo medieval no las evocaban en su confrontación, sino que las percibían de forma indiferenciada (Nieto Soria, 2004: 710).
}

titud del autor y su propósito. Partiendo del acuerdo en considerar la sátira un ataque basado en la ruptura de un ideal, cabría diferenciarla, por su impersonalidad, de la invectiva, es decir, el ataque personal. También hay que advertir que, pese a nuestro énfasis en la crítica política, esta muchas veces se mezclaba y confundía con la crítica moral, tomando la forma, en su mayoría, de coplas y decires, composiciones comunes en la poesía castellana de la época ${ }^{15}$. Aunque en menor medida, también es posible hallar críticas en la prosa, en la narración de algunas fabliellas y, ya entrado el siglo XVI, incluso en escritos burlescos que parodian, incluso en su título, el género cronístico.

Por otro lado, la historiografía castellana de este siglo ha sido valorada, respecto a otras épocas del Medievo, por su variedad y riqueza. Tal florecimiento se ha asociado a un cambio en las relaciones entre la escritura histórica y el poder, así como a una nueva valoración de la memoria histórica y su influencia en el presente ${ }^{16}$. Todo ello, sumado a otros factores, motivó una presencia mayor del análisis político en los textos cronísticos, que jugaron un papel importante en los conflictos coetáneos. De manera especial, es necesario subrayar el interés por las crónicas regias, cuyo poder legitimador se veía reforzado al ser consideradas como una narración autorizada con garantías de verosimilitud, condición derivada de la inclusión de documentos procedentes de la cancillería y de la cercanía al entorno cortesano (Bautista, 20I5: 98, I09). Esto las convertía en piezas muy atractivas para los intereses de los diversos actores políticos del momento y, por este motivo, muchas sufrían alteraciones posteriores por manos distintas a las de su autor.

En conjunto, las crónicas regias y las obras satíricas constituyen ejemplos de ejercicios retóricos que afectaban a toda la corona y, especialmente, al núcleo del poder, la corte, no casos individualizados, como podría

\footnotetext{
${ }^{15}$ En los decires bajomedievales se ha situado el origen de la subjetividad literaria en Castilla. Para Ortega Sierra (2017: 310), los «dezidores» castellanos serían «un círculo exclusivo de letrados, nobles y altos burgueses con cargos prestigiosos en el aparato administrativo de un poder monárquico en plena expansión".

${ }^{16}$ Entre otros, lo ha señalado uno de los mejores conocedores de la materia (Tate, 1970: 28I).
} 
ocurrir con las crónicas particulares, de tipo biográfico o local. Este factor anuncia alguna de las hipótesis sobre los sujetos de la crítica, puesto que, en función del objetivo de la obra, existía un mayor o menor abanico de personajes, los protagonistas pertenecían al entorno cortesano o urbano, etc.

A continuación, vamos a desarrollar algunos de los conceptos reivindicados por los ED - y nombrados en el segundo apartado de este artículo- que pueden abordarse en el análisis de los textos bajomedievales para el estudio de sus implicaciones de crítica política. No se tratará de una relación exhaustiva de casos, sino de ejemplos que demuestren la aplicabilidad de esta perspectiva de investigación a diferentes fuentes del siglo Xv.

\subsection{Construcciones discursivas Y CONTESTACIÓN POLÍTICA}

Para Van Dijk, probablemente el máximo exponente de los ECD en la actualidad, estos estudios deberían combinar discurso, cognición y sociedad con la dimensión histórica y cultural. La cognición, es decir, la interfaz entre discurso y sociedad, tendría como principal consecuencia las representaciones (socio)mentales. Estas representaciones podrían considerarse como el elemento base del resto de procesos: la interpretación de realidades y la elaboración de modelos mentales condicionarían actitudes e ideologías que, finalmente, influyen en el discurso y otras prácticas sociales ${ }^{17}$. No obstante, según F. Dosse (2006: I28), como resultado del giro lingüístico y las tendencias constructivistas de Foucault y otros autores, el estudio de las representaciones en la disciplina histórica daría paso después al de las "construcciones discursivas", siendo dos de las más importantes la ideología y la identidad — con su opues-

\footnotetext{
${ }^{17}$ Tomando el ejemplo del racismo, uno de los objetos de estudio de Van Dijk, éste se definiría no como prejuicios de fanáticos individuales, sino como un conjunto de «representaciones cognitivas de grupos, socialmente compartidas, es decir, de actitudes e ideologías». Afirma que éstas «están en la base de prácticas sociales racistas tales como el discurso discriminatorio y otras formas de discriminación” (Van Dijk, 2009: I4-39). Sobre la relación entre las construcciones cognitivas y las representaciones sociales, véase la síntesis de Jean Maisonneuve (2017: I03-II5).
}

to, la otredad o alteridad-, que trataremos ahora.

La primera es entendida por Van Dijk como cognición social, las creencias de un grupo y sus miembros un sistema de ideas que fundamenta una serie de prácticas sociales. Si bien ideologías y valores conforman la memoria social, estos últimos tienen una función cultural más general, ya que son válidos y aceptados socialmente por todos los grupos. Estos «fundamentos comunes» se interpretan normalmente como la base de las ideologías (Van Dijk, 2003: 16-25). En las fuentes castellanas bajomedievales — no solo en las narrativas, sino también en otras, de carácter jurídico, documental... - encontramos una serie de conceptos que sirven de marcadores ideológicos, al tiempo que se utilizan para describir o evaluar las actuaciones de diferentes miembros de la sociedad política. A pesar de su versatilidad, es posible identificar algunas categorías conceptuales generales, cuatro de las cuales pasamos a describir como ejemplos. Así, en primer lugar, pueden observarse valores vinculados a la relación con los monarcas: «servicio», «obediencia», «lealtad»... Vemos un ejemplo en la sentencia contra el conde de Castrojeriz, recogida en la Crónica del Halconero:

En ausençia, contumaçia e rrebeldía del dicho conde de Castro, declaramos al dicho don Diego Gomes, por las cosas sobredichas [...] auer sido desobediente al dicho señor Rey, e no auer guardado ni guardar en todo ello su seruicio, e averle deseruido e desseruyrle (Carrillo de Huete, I946: II7).

Estos términos implican una dependencia personal, por lo que se supeditan al rey, que aparece mencionado explícita o implícitamente. Su estudio pormenorizado en las distintas fuentes mostraría la mayor o menor prevalencia en la Edad Media tardía de ese ideal social basado en este tipo de relaciones privadas - donde las infracciones se realizan contra una persona a la que se está unido por un compromiso de respeto y fidelidadque habían impregnado la ideología política.

Por otro lado, pueden observarse términos de tipo político-jurídico: «bien común», «tiranía», «ley», «jus- 
ticia», "derecho»... Las reprobaciones de ciertos individuos por incumplimiento de estas normas provenían a menudo de los monarcas ${ }^{18}$, pero también de otros personajes. Por ejemplo, los nobles de la facción de Enrique IV durante el conflicto con su hermanastro Alfonso, consideraban, según la Crónica anónima de Enrique IV (1991: 206-207), que aquellos que llamaban rey a este actuaban en menosprecio de las leyes ${ }^{19}$. En el pensamiento castellano del siglo xv la tiranía ocupaba el lugar opuesto al buen gobierno y se revelaba como una de las más temibles amenazas de la estabilidad política $^{20}$. Fernando de Pulgar recogía la actuación de García Osorio, corregidor de Salamanca, contra Rodrigo Maldonado, un caballero vecino de la ciudad, cuyo comportamiento describía en estos términos:

\begin{abstract}
Ynformó al Rey que aquel cauallero biuía mal, \& tenía tiránicamente el castillo de Monleón, que es de aquella çibdad, bien çercano al reyno de Portogal, en el qual avía labrado moneda sin actoridad real, e avía fecho e cometido otros grandes crímenes \& delictos, en deservicio de Dios \& suyo, e daño de toda la tierra, la qual tenía muy opremida con robos \& tiranías (Pulgar, 1943: 302) ${ }^{21}$.
\end{abstract}

En tercer lugar, se pueden identificar nociones procedentes de la cultura caballeresca y noble, como «honor» u «honra», «fama» o «linaje», entre otras. Se trataba de

\footnotetext{
${ }^{18}$ Juan II, en una carta recogida en la Crónica del Halconero (1947: 273), recriminaba al adelantado Manrique y al almirante Fadrique su "codicia desordenada, envidia, malquerencia», acusándoles de desobediencia, rebeldía y perturbación del «bien común» con la propagación de infamias contra Álvaro de Luna.

${ }^{19}$ En un sentido similar, Pedro Mexía (1945: 255) defendía que el servicio al rey era obligado por «las leyes humanas y de cauallería, pero también las diuinas y santas».

${ }^{20}$ Tras la recepción de ideas políticas italianas en torno al concepto de tiranía, pueden reconocerse dos tipos de perspectivas: una visión tradicional, vinculada a la moral religiosa y al concepto de pecado, frente a la que la comunidad debe someterse a la Providencia, y otra novedosa que la fundamenta en un delito jurídico-político y permitía la resistencia (Nieto Soria, 2004: 714). Se ha sostenido que a partir del golpe de Záfraga, el in de mayo de I448, el uso del término tiranía se usó ampliamente en todo el reino para referirse al gobierno de Álvaro de Luna (Nieto Soria, 2017: 287; Carceller Cerviño, 2009: 9I-93).

${ }^{21}$ De manera más aséptica, Valera afirmaba que Maldonado hacía daños desde la fortaleza de Monleón, por lo que fue castigado por los monarcas (Valera, 1927: 126-127).
}

valores que, además, los grupos poderosos utilizaban para legitimar su preeminencia social. No obstante, en los últimos siglos medievales se denunció la escasa correspondencia entre estos ideales y la realidad, al verse corrompidos a menudo por los fines materiales, según declaraban autores como Diego de Valera ${ }^{22}$. El honor y el linaje, como valores de la cultura caballeresca empleados en la propaganda nobiliaria, también se utilizaban para enfatizar sus trasgresiones de la norma. Vinculada a ellos estaba la idea de fama, cuyo papel en la mentalidad medieval ha sido estudiado en varias ocasiones $^{23}$.

Carrillo de Huete dejaba por escrita la importancia de estos aspectos en unas palabras del conde de Castro, donde este defendía que los caballeros virtuosos debían guardar prioritariamente, además de su fe, «al ánima de pecado, e después su persona e corona e onor e fama ${ }^{24}$. En la Batalla campal de los perros contra los lobos, Alonso de Palencia subrayaba la importancia del linaje entre los lobos con el habla del anciano Gravaparón (Martín Romero, 20I3: II5-II6; Corral Sánchez, 20I8b: 646). Mediante el empleo de estos mismos conceptos, en la segunda parte de la Crónica de Juan II se recogen en estilo indirecto las palabras del obispo de Palencia sobre Juan de Sotomayor, maestre de Alcántara, por coaligarse con los infantes de Aragón y actuar contra las órdenes del rey: «sobre todo le dijo que como quier que estas cosas malas é feas había fecho en gran deshonra é denuesto de su persona é estado é linaje, que todo se podía bien remediar veniéndose para el Rey, la Merced del cual gelo perdonaría todo» (Crónica de don Juan II de Castilla, I842-I896: 338-34I).

Por último, también podemos hallar términos de carácter moral que reforzaran los argumentos o protestas, habida cuenta del peso de lo religioso en esta sociedad.

\footnotetext{
22 «Ya son mudados por la mayor parte aquellos propósitos, con los quales la caballería fue comenzada: estonce se buscaba en el caballero sola virtud, agora es buscada caballería para no pechar» (Valera, 1959: 107).

${ }^{23}$ Carrasco Manchado (2000: IOI), diferenciando entre la «fama-rumor y la fama-reputación", defiende que quebrar la reputación del contrario era una forma de destruirlo desde el punto de vista propagandístico.

${ }^{24}$ Se lamentaba, por este motivo, de que, si el rey actuaba contra ellos, "serían forçados en todo rreproche de ley de Dios e de onesta orden e vien de Cauallería, e grande peligro de sus ánimas, e denuesto de su onor e fama, en cuyo rrespeto toda cosa tenporal es nada» (Carrillo de Huete, I946: 84).
} 
Así, se aprecia la utilización de términos como "herejía» o alusiones a diferentes pecados, entre los que destacan los capitales. Por ejemplo, Fernán Pérez de Guzmán (1998: I87-I88), en las recensiones biográficas de sus Generaciones y semblanzas, condenaba la codicia de algunos aristócratas ambiciosos que buscaban su engrandecimiento a costa de la "patria»: «No es de perdonar la cobdicia de los grandes caballeros, que por crecer e aventajar sus estados e rentas, posponiendo la consciencia y el amor de la patria por ganar ellos, dieron lugar a ellos [los males]».

Si bien podía hacerse referencia a estos valores comunes de forma implícita, mediante metáforas o comparaciones más sutiles, hemos recogido aquí menciones explícitas, lo que evidencia la importancia del léxico y la conceptualización de las ideas ${ }^{25}$. Esta razón podría llevarnos a priorizar las fuentes elaboradas en castellano, pues, pese a la importancia de ciertas obras redactadas en latín para el estudio de la contestación política - por ejemplo, las Décadas de Alonso de Palencia-, realizar una comparación paralela de textos en distintos idiomas podría resultar sesgado. Sobre todo, si se utilizan traducciones modernas que han podido adulterar, aunque sea mínimamente, el significado original, debido a los distintos matices que pueden tener los vocablos. Por supuesto, esto no es óbice para consultar dichas fuentes, cuyo contenido es sumamente interesante en dicho ámbito y fundamental para enriquecer una interpretación general.

¿Qué relación guarda la ideología con estos usos del lenguaje? Algunos autores, como Derrida, Foucault y Levi-Strauss, llegaron a anteponer la lengua a los individuos, rechazando la concepción del lenguaje sólo como instrumento y defendiendo su capacidad de crear y definir a la sociedad. Por el contrario, el modernista

\footnotetext{
${ }^{25}$ Dicha premisa está en la base de los métodos lexicométricos en los estudios históricos, como los que han utilizado, para el caso castellano, Carrasco Manchado (2007) y Foronda (2013). En este sentido, reviste especial interés el Corpus Diacrónico del Español (CORDE) desarrollado por la Real Academia Espańola. Este corpus, que cuenta con 250 millones de registros textuales de géneros muy dispares, incorpora útiles herramientas de búsqueda para análisis de colocaciones léxicas desde los inicios del castellano hasta 1974. También Carrasco Manchado (20II) ha abordado las posibilidades que ofrece el CORDE para la historia medieval.
}

Peter Burke ha considerado que estos son argumentos simplistas y no distinguen que hay personas que controlan el lenguaje y que lo utilizan para controlar a otros, como los especialistas de la persuasión — sofistas, humanistas...-. No habría que pensar, por tanto, que todos ellos crean en la propaganda o sean indiferentemente cínicos ante ella, sino que se situarían en un lugar intermedio que podría definirse en el sentido de «ideología» de Althusser como la «relación imaginada de los individuos con respecto a sus reales condiciones de existencia» (Burke, 1996: 39-40). A la hora de abordar estas cuestiones, asimismo, es interesante también recordar la noción de habitus, desarrollada por Pierre Bourdieu (1994: 2I). Se entiende por habitus a los esquemas generativos conformados por los agentes sociales a lo largo de sus experiencias y aprendizajes, es decir, esquemas estructurados, pero también estructurantes, puesto que a partir de ellos se producen ideas y percepciones. Todos estos aspectos deberían ser tratados de manera individualizada en cada fuente, para procurar un acercamiento lo más completo posible a las motivaciones y la ideología de los autores estudiados.

Considerando que los diferentes agentes políticos bajomedievales necesitaban legitimar sus actuaciones mediante distintos tipos de retóricas, hemos de reconocer la participación de estos «hombres del saber» en defensa de la nobleza y las ciudades. Por un lado, la función de los cronistas era relatar los acontecimientos más relevantes y elaborar un registro de estos. Sin embargo, esta ocupación no escapó de las necesidades políticas, de los choques de intereses ni de los enfrentamientos ideológicos. La tarea quedaba convertida a veces en una "escritura militante $»^{26}$. Merece la pena preguntarse el porqué de la elección de unos u otros sucesos, de dar voz a determinados personajes o utilizar ciertos marcadores ideológicos, es decir, de cuestionarse sobre lo implícito y lo explícito, aunque no siempre sea posible encontrar una respuesta conclu-

\footnotetext{
${ }^{26}$ Fernando de Pulgar justificaba en una carta al conde de Cabra que los cronistas tenían licencia para añadir algún razonamiento si este no escapaba "de la sustançia del fecho» y, como sostiene Gonzalo Pontón (2008: LXVI), otras veces se optaba por silenciar detalles, antes que por la mentira, pues «el criterio de la verdad» era laxo.
} 
yente. Lo mismo podríamos plantear para los autores de la literatura satírica.

En el análisis de la ideología de un discurso hay que tener en cuenta, además, la representación con la que se caracteriza e identifica a los grupos sociales que se mencionan en él ${ }^{27}$. El discurso sirve a los grupos sociales para definirse a sí mismos y diferenciarse de otros, lo que muestra la estrecha relación existente entre la ideología, la construcción de identidades y, necesariamente, de alteridades, parte de esas «representaciones cognitivas» $\mathrm{o}$ "construcciones discursivas» de las que hablamos ${ }^{28}$. Ya se les denomine de un modo u otro, lo cierto es que este fenómeno puede identificarse en las fuentes siguiendo las indicaciones de Van Dijk sobre los elementos discursivos que los determinan. Retomamos la interrogación sobre lo implícito y lo explícito: según, Van Dijk (2003b: 48), en los discursos se refuerzan las características positivas propias frente a las negativas de los grupos «contrarios» por medio del énfasis y de la explicitud. Por otro lado, las características negativas propias y las positivas ajenas sufren un proceso inverso de brevedad y tendencia a lo implícito. En muchas de las fuentes bajomedievales con las que contamos resulta difícil analizar la identidad de su creador, puesto que no siempre registra sus características o actuaciones. No obstante, sí que es posible analizar las representaciones sociales a partir de las anteriores apreciaciones de Van Dijk, así como las de otros autores (Maisonneuve, 20I7: IO3-II5). Un conocido ejemplo al que podemos aludir es la figura de Fernando de Antequera, ampliamente alabada en textos como las Generaciones y semblanzas de Pérez de Guzmán (1998: 79-87). Asimismo, en la primera parte de la Crónica de Juan II, al infante, pos-

\footnotetext{
${ }^{27}$ La asunción de unos referentes por parte de un conjunto de individuos supone la construcción de una identidad política, es decir, una estructura compartida de actitudes que explicaría determinadas relaciones. A este respecto, Oliva Herrer (20II: 366) ha sostenido que lo fundamental es comprobar la existencia de dicha estructura y su grado de difusión en la sociedad.

${ }^{28} \mathrm{La}$ construcción de la identidad propia de un colectivo o sociedad es un proceso que conlleva necesariamente el reconocimiento de una alteridad de la que distinguirse. En esta dialéctica entre identidad y alteridad, el sujeto agente produce una serie de imágenes sobre sí mismo, pero también, sobre el «otro» diferente que, a partir de prejuicios y parcialidades, tienden a anular a este último. Siguiendo a Benito Ruano (1988: 16-18), abordamos esta cuestión hace ya unos ańos (Corral Sánchez, 20I5: 13).
}

terior rey de Aragón, se le representa como un gobernante ideal rodeado de consejeros desleales e intrigantes cortesanos contra los que debía actuar en pos de la armonía del reino:

Y el Infante acordó de embiar por los del Consejo del Rey [...] é les rogó afectuosamente que hablasen con la Reyna, é le diesen á entender quanto deservicio rescibia, en creer algunos que le daban mal consejo, é trabajaban como ella estuviese siempre en discordia con el Infante, é á esta causa ellos ganan con Su Señoría, y el Reyno totalmente se destruye. Y ellos le respondieron: «Señor, si vos no mandais apartar de aquí estos malos consejeros que la Reyna tiene, nunca cosa de bien se hará» (Galíndez de Carvajal, I779: 69).

Esta representación no era pasiva, sino fundamentalmente activa: el infante se definía por sus palabras y sus actos. De este modo, en las argumentaciones atribuidas a Fernando de Antequera es posible hallar la conexión entre los intereses particulares de dichos cortesanos y la pérdida del reino, a través de los malos consejos ofrecidos a la reina Catalina de Lancaster — su compañera en la regencia durante la minoridad de Juan II-, que provocaba una mengua de justicia y que los propios regentes dejaran de ser temidos. Los males sufridos en Castilla se hacían derivar de la conducta egoísta de unos «otros», a los que se oponía la tarea de orden del infante. Por otro lado, cabe mencionar que estas representaciones podían afectar a la vida pública o a la privada.

La cuestión de las alteridades y la creación de unos «otros» negativos conduce inevitablemente a la noción de conflicto. Del mismo modo que es necesario para el acuerdo, el discurso también es fundamental para expresar y crear desacuerdos. Por tanto, es importante tener en cuenta la relación de los conflictos existentes en la sociedad con las representaciones o construcciones discursivas ${ }^{29}$. Los

\footnotetext{
${ }^{29}$ Como señala Tomás Albaladejo (20II: 46), el conflicto «tiene su primera y más directa manifestación en el discurso".
} 
discursos funcionan como soporte comunicativo de los conflictos y sirven como instrumento de los distintos actores sociales para posicionarse de una $u$ otra forma. Al final de la Edad Media, además, se observa una "progresiva tendencia a la ideologización de los conflictos», que fomentaba la producción de discursos en la lucha política (Nieto Soria, 2007: 46). Los discursos de contestación, por su propia definición, están indisolublemente unidos a las tensiones políticas que afectaban a la sociedad castellana de estos momentos. Aunque sus características son muy variables, en las fuentes narrativas encontramos fundamentalmente conflictos relativos a la gobernación del reino - el caso que acabamos de citar en el párrafo anterior-y aquellos que, a menudo en conexión con estos, afectaban a entornos regionales más concretos, como luchas por el poder local. En este sentido, podría ser interesante trabajar con este tipo de fuentes adaptando los modelos de análisis diseñados por otros medievalistas para estudiar dichos contextos locales (Jara Fuente, 20II, 20I3a, 20I3b).

En cuanto a la creación de antagonismos, habría que destacar los estudios de Rodríguez de las Heras (I98I) sobre regulaciones del discurso. Si bien está enfocada a los discursos parlamentarios contemporáneos, esta propuesta teórico-metodológica aporta algunas luces sobre cómo hallar el enfrentamiento en el discurso político, guardando esto también relación con la construcción de alteridades negativas ${ }^{30}$. Su aplicación podría ser interesante en discursos de carácter más directo, como los que pueden encontrarse en la documentación cancilleresca — sobre todo en las cartas—, los cuadernos de peticiones de Cortes o los testimonios recogidos en los procesos judiciales. No obstante, creemos que esta debería hacerse con las debidas cautelas, al ser una metodología diseñada para estudios contemporáneos y que por el momento - que sepamos — no se ha adaptado a las fuentes medievales.

\footnotetext{
${ }^{30}$ Las siete regulaciones sugeridas por este autor son las siguientes, ordenadas de manera gradual: las regulaciones suaves (sublimación y favor), las regulaciones medias (desviación, miedo, culpabilidad), y las regulaciones duras (represión y expulsión). De ellas, nos interesarían en especial las de intensidad media y dura, ya que reflejan el antagonismo de una forma más clara.
}

Como últimos elementos discursivos que trataremos aquí, debemos contemplar los procesos de propaganda y legitimación como claves, no sólo en las situaciones de conflicto o dominación, sino en cualquier intento de reconocimiento social. Como sostiene Ana I. Carrasco (2000: IOO), «lo que revela este uso de la propaganda es la necesidad de respaldar la legitimación política para determinadas acciones o personas». Lo inverso ocurre con los procesos contrarios, la contrapropaganda y la deslegitimación, que sirven para anular la autoridad de otros actores y donde confluyen, además, las categorías ideológicas e identitarias —ellos/nosotros- del discurso $^{31}$. La utilización de argumentaciones como la de Fernando de Antequera, así como de otros recursos retóricos, como metáforas ${ }^{32}$, analogías histórico-religiosas $^{33} \mathrm{o}$ citas de autoridades ${ }^{34}$.

$\mathrm{Al}$ alabar a unos, y criticar a otros se establecían modelos de comportamientos correctos coincidentes con los valores e ideales que debían definir la sociedad. No obstante, más allá de la intención propagandística, la censura podía partir de una voluntad didáctica o convertirse, en último término, en una enseñanza. Esta apreciación nos remite al carácter ejemplarizante de parte de la literatura castellana mediante la inclusión de exempla o el uso de diversos tipos de comparaciones

\footnotetext{
${ }^{31}$ Véase el juego de propaganda-contrapropaganda en torno a la cuestión dinástica en la Guerra de Sucesión Castellana, estudiado por varios autores y del que hemos ofrecido una síntesis reciente (Corral Sánchez, 20I8c).

${ }_{32}$ Entre estas, destacó la presencia de las identificaciones con animales. Por ejemplo, la cobardía se representaba con aves o zorros escondidos — „tornósele el corazón / más chico que de un pardal» (Manuel de Lando, 1989: 85) — y la sańa violenta, con leones perros o lobos. No obstante, debe tenerse en cuenta que la diversidad de la tradición literaria previa ocasionaba interferencias y confusiones en los rasgos atribuidos a cada animal. Por ejemplo, el león podría corresponderse con la valentía y el perro, con la fidelidad (Nogales Rincón, 20II: 285$)$.

${ }^{33}$ Un tema frecuente en las comparaciones históricas era el final del reino visigodo como espejo de la situación de caos. Enríquez del Castillo recogía en su crónica algunas palabras del pregón de la sentencia a Alonso Carrillo, arzobispo de Toledo, en las que se le comparaba con Oppas, célebre obispo visigodo: «Syguiendo las pisadas del obispo don Opas, el traydor, destruidor de las Españas, avía seydo traydor a su rrey y su seńor natural, rrevelándose contra él» (Enríquez del Castillo, 1994: 242). La mención a Oppas entroncaba con la tradición cronística hispánica cristiana, que destacaba a este personaje como el colaboracionista con los musulmanes por antonomasia (Pérez de Tudela y Velasco, 20II).

${ }^{34}$ Las sentencias, especialmente de procedencia bíblica, pueden encontrarse en diversas crónicas de todo el siglo (Galíndez de Carvajal, I779: 292; Valera, 1941: 277, Enríquez del Castillo, 1994: 238; Crónica anónima de Enrique IV de Castilla, 1991: 456).
} 
o pronósticos (MacKay, 1985; Bizzarri, 20I4). Esto es, si bien la contrapropaganda estaba destinada a conducir a la deslegitimación y la creación de una alteridad — desacreditar al «otro»—, estos dos procesos podían acabar siendo, igualmente, consecuencia de otro tipo de estrategias discursivas, como la didáctica. Por tanto, al margen de su intención particular, hay que valorar la deslegitimación de ciertos individuos o colectivos como una posible consecuencia indirecta de la parénesis.

\section{CONCLUSIONES}

En paralelo a los ED, son cada vez más los historiadores que se acercan a las sociedades del pasado a través de su vertiente cultural y comunicativa. Este interés ha dejado su impronta también en los estudios sobre el periodo bajomedieval, con acercamientos muy interesantes tanto en el ámbito europeo como en torno a la Corona de Castilla. Gracias a las aportaciones de estos ámbitos de estudio, disponemos de un aparato teórico muy completo a partir del cual desarrollar investigaciones con nuevos enfoques. En este trabajo hemos tratado de ofrecer un ejemplo de ello.

Una vez que se comprende el funcionamiento de ciertos recursos discursivos, es posible leer las fuentes medievales con otra perspectiva. Así, fenómenos como las representaciones sociales, la ideología o la legitimación nos han servido para mostrar diversas posibilidades de estudio de los textos narrativos castellanos de esta época. Además, se ha puesto el énfasis concretamente en las estrategias destinadas a reprobar los comportamientos o actitudes de algunos miembros de la sociedad política, especialmente de individuos pertenecientes a la aristocracia. Aunque este tipo de fuentes se revela de gran interés para los estudios de enfoque discursivo, sobre todo por la riqueza de su contenido, consideramos, no obstante, que el empleo de otros materiales documentales, relativos a entornos más concretos, daría pie a estudios de gran interés y carácter más localizado.

Esperamos ofrecer en próximas publicaciones otros ejemplos de aplicación de esta propuesta más desarrollados y concretos que permitan comprender mejor determinados fenómenos sociopolíticos del periodo. No obstante, siendo conscientes de que el avance académico se basa en contrastar y compartir modelos y resultados, deseamos que la propuesta metodológica planteada sucintamente en este artículo pueda, de algún modo, contribuir al trabajo de otros historiadores y servir como guía para futuros estudios en torno a cuestiones discursivas en la historia medieval. 


\section{BIBLIOGRAFÍA}

Albaladejo, Tomás (20II): «Los discursos del conflicto y los conflictos del discurso. Análisis interdiscursivo y Retórica cultural», en Macedo, Ana Gabriela, Mendes de Sousa, Carlos y Moura, Vítor (coords.), Vozes, Discursos e Identidades em Conflito, Braga, Húmus, Centro de Estudos Humanísticos, Universidade do Minho, pp. 4I-6o.

Almuiña Fernández, Celso Jesús (2007): «Introducción», en Nieto Soria, José Manuel et al., Propaganda y opinión pública en la historia, Valladolid, Universidad de Valladolid, pp. 3-IO.

Asenjo González, María (1999): «Las ciudades», en Nieto Soria, José Manuel (dir.), Orígenes de la monarquía hispánica: propaganda y legitimación (ca. I400-I520), Madrid, Dykinson, pp. I05-I40.

Austin, John L. (1982): Cómo hacer cosas con palabras: palabras y acciones, Barcelona, Buenos Aires, Paidos.

Barbero, Miguel Ángel, Estrella, Jorge Raúl (2006): «Literatura e historia: ¿crítica antinobiliaria o literatura de facción? Castilla, siglos XIV y XV», Fundación, n. 8, pp. 187196.

Barbosa Schiavinato, Rodrigo (20I8): «Historiografia e legitimação de poder na baixa idade média peninsular (Portugal e Castela)», História Revista, vol. 23, n. I, pp. I48162.

Bautista Pérez, Francisco (20I5): «Historiografía y poder al final de la Edad Media: en torno al oficio de cronista», Studia Historica. Historia Medieval, vol. 33, pp. 97117.

Beceiro Pita, Isabel (2000): «Los cambios en el discurso político de la nobleza castellana durante la Baja Edad Media", Cahiers d'études romanes, n. 4 , pp. 45-62.

Benito Ruano, Eloy (1988): De la alteridad en la historia, Madrid, RAH.

Bizzarri, Hugo (20I4): «Pero López de Ayala y la tradición del exemplum», en Alvar, Carlos (coord.), Formas narrativas breves: lecturas e interpretaciones, San Millán de la Cogolla: Cilengua, pp. 6I-84.

Boucheron, Patrick, y Offenstadt, Nicolas (Dirs.) (20II): L'espace public au Moyen Âge: débats autour de Jürgen Habermas, Paris, Presses Universitaires de France.

BouHAÏK-GIRONÈs, MARIE (2007): «L'historien face à la littérature: à qui appartiennent les sources littéraires médiévales?», en Actes des congrés de la Société des historiens médiévistes de l'enseignement supérieur public, Paris, Publications de la Sorbonne, pp. I5I-16I.

Bourdieu, Pierre (1987): Ce que parler veut dire: l'économie des échanges linguistiques. París: Fayard.

Bourdieu, Pierre (1994): Raisons pratiques: sur la théorie de l'action, Paris, Seuil. Burke, Peter (1996): Hablar y callar: funciones sociales del lenguaje a través de la historia, Barcelona, Gedisa.

Cabrera Acosta, Miguel Angel (20I0): «La investigación histórica y el concepto de cultura política», en Pérez Ledesma, Manuel y Sierra Arroyo, María (coords.), Culturas políticas: teoría e historia, pp. 19-85.

Carceller Cerviño, María del Pilar (2009): «Álvaro de Luna, Juan Pacheco y Beltrán de la Cueva: un estudio comparativo del privado regio a fines de la Edad Media», En la España medieval, n. 32, pp. 85-II2.

Carrasco Manchado, Ana Isabel (1998): «Aproximación al problema de la consciencia propagandística en algunos escritores políticos del siglo xV", En la España Medieval, n. 21, pp. 229-269.

Carrasco Manchado, Ana Isabel (2000): Discurso politico y propaganda en la Corte de los Reyes Católicos (I474-I482), tesis doctoral, Universidad Complutense de Madrid.
Carrasco Manchado, Ana Isabel (2007): «Léxico político en el Seguro de Tordesillas: conflicto, pactos y autoridad real», en Foronda François, Ana Isabel Carrasco Manchado (eds.), Du contrat d'alliance au contrat politique: cultures et sociétés politiques dans la Péninsule Ibérique de la fin $d u$ Moyen âge, Toulouse: CNRS, Université de Toulouse-Le Mirail, pp. 85138.

Carrasco Manchado, Ana Isabel (20II), «Nuevas herramientas para LA Historia de la Edad Media hispánica: los corpus textuales informatizados", En la España Medieval, vol. 34, pp. 343-372.

Carrillo de Huete, Pero (1946): Crónica de Juan II, edición de Juan de Mata Carriazo, Madrid: Espasa Calpe.

Challet, Vincent (20I2): «Discordancias y comunicación política en el seno del consulado montpellerino a fines de la Edad Media: Nemine discrepante?», Edad Media: Revista de Historia, n. 13, pp. I43-16I.

Chilton, Paul (2004): Analysing political discourse: theory and practice, Londres: Routledge.

Córdoba de la Llave, Ricardo (20I4): «Conflictividad social en los reinos hispánicos durante la Baja Edad Media. Aproximación historiográfica», Vinculos de Historia, n. 3, pp. 34-53.

Corral SÁnCheZ, Nuria (20I5): «Alteridad y patrimonio: la representación del musulmán en la iconografía medieval castellanoleonesa», en Identidad y patrimonio, Salamanca, Instituto de las Identidades, Diputación de Salamanca, pp. 13-36.

Corral SÁNChez, Nuria (20I8A): «La literatura como arma política: ideas y representaciones contra la élite nobiliaria», en Bermúdez López, Jesús et al. (coords.), El conde de Tendilla y su tiempo, Granada, Universidad de Granada, pp. 305319.

Corral Sánchez, Nuria (20i8B): «Perros contra lobos. Ideología política y ¿̇sátira antinobiliaria? en una obra de Alonso de Palencia», Anuario de Estudios Medievales, vol. 48, n. 2, pp. 639-668.

Corral Sánchez, Nuria (20I8c): «Dios salve a las reinas. Propaganda y legitimación en la Guerra de Sucesión castellana (I475-I479)", Ammentu. Bollettino Storico e Archivistico del Mediterraneo e delle Americhe, vol. I, n. I2, pp. 35-48.

Corral SÁnchez, Nuria (2019): «Expresiones de oposición a la injerencia nobiliaria en las ciudades castellanas. Una aproximación discursiva desde la cronística bajomedieval». En Monsalvo Antón, José María (ed.), Élites, conflictos y discursos políticos en las ciudades bajomedievales de la Península Ibérica, Salamanca, Universidad de Salamanca, pp. I89-2I2.

CRÓNICA ANÓNIMA DE ENRIQUE IV DE CASTILLA (1454-1474): Crónica castellana, (199I): edición de María Pilar Sánchez-Parra, Madrid: Ediciones de la Torre, vol. 2.

CRÓNICA DE DON JUAN II DE CASTILla (1842-1896), COLECCIÓN DE DOCUMENtos inéditos para la Historia de España (CODOIN), Madrid, Imprenta de la Viuda de CALero, vol. 99, Pp. 79-465 y vol. ioo, pp. I-409.

Dacosta, Arsenio (20I6): «A propósito de un aparente silencio: la memoria genealógica escrita de la nobleza peninsular en la baja Edad Media», Tiempos Modernos, Vol. 8, n. 32, pp. 73-87.

Deyermond, Alan (1988): «La ideología del Estado moderno en la literatura española del siglo XV», en Rucquoi, Adeline (coord.), Realidad e imágenes del poder: España a fines de la Edad Media, Valladolid, Ámbito, pp. I7I-193.

Di Camillo, OtтAvio (199i): «¿Existe una literatura de oposición en la España de fines de la Edad Media?», en Adeline Rucquoi (dir.), Genèse médiévale de l'Espagne Moderne. Du refus a la revolte: les resistances, Nice, Université de Nice, pp. I43-I69. 
Dosse, FrançoIs (2006): La marcha de las ideas. Historia de los intelectuales, historia intelectual, Valencia, Universidad de Valencia.

Dumolyn, Jan (20I2): «Political communication and political power in the Middle Ages: a conceptual journey», Edad Media: revista de historia, $\mathrm{n}$. I3, pp. 33-55

Enríquez del Castillo, Diego (1994): Crónica de Enrique IV, edición de Aureliano Sánchez Martín, Valladolid, Universidad de Valladolid.

Fairclough, Norman (1995): Critical discourse analysis: the critical study of language, Harlow, Essex, Longman.

Foronda, François (2004): «La "privanza" dans la Castille du bas Moyen Age: Cadres conceptuels et stratégies de légitimation d' un lien de proximité», en Isabel Alfonso Antón, Julio Escalona Monge, Georges Martin (coords.), Lucha politica: condena y legitimación en la España medieval, Lyon, ENS Éditions, pp. 153198.

Foronda, François (2013): El espanto y el miedo. Golpismo, emociones politicas y constitucionalismo en la Edad Media, Madrid, Dykinson.

Foucault, Michel (1983): El orden del discurso, Barcelona, Tusquets.

Fow ler, Roger ET AL. (1983): Lenguaje y control, México, Fondo de Cultura Económica.

Franco Silva, Alfonso (20I2): Los discursos políticos de la nobleza castellana en el siglo $X V$, Cádiz, Universidad de Cádiz.

Galíndez de Carvajal, Lorenzo (1779): Crónica del señor rey Don Juan, segundo de este nombre en Castilla y en Leon, Valencia: imprenta de Benito Monfort.

Gamberini, Andrea, Genet, Jean-Philippe, Zorzi, Andrea (eds.) (20iI): The Languages of Political Society: Western Europe, I4th-I7th Centuries, Roma, Viella.

Gauvard, Claude (2007): «Introduction», en Challet, Vincent et al., La sociedad politica a fines del siglo XV en los reinos ibéricos y en Europa: ¿élites, pueblo, súbditos?, Paris, Valladolid, Publications de la Sorbonne, Universidad de Valladolid, pp. II-20.

Genet, Jean-Philippe (2007): «Les langages de la propagande», en Challet, Vincent et al., La sociedad politica a fines del siglo XV en los reinos ibéricos y en Europa: ¿élites, pueblo, súbditos?, Paris, Valladolid, Publications de la Sorbonne, Universidad de Valladolid, pp. 89110.

Genet, Jean-Philippe (2009): «Modelos culturales, normas sociales y génesis del Estado Moderno», en Boucheron, Patrick y Ruiz Gómez, Francisco (eds.), Modelos culturales y normas sociales al final de la Edad Media, Cuenca, Casa de Velázquez, Universidad de Castilla-La Mancha, pp. 17-38.

Gibello Bravo, Víctor Manuel (1999): La imagen de la nobleza castellana en la Baja Edad Media, Cáceres, Universidad de Extremadura.

Gómez Redondo, Fernando (1998-2007): Historia de la prosa medieval castellana, Madrid, Cátedra, 4 vols.

Habermas, Jürgen (1997): Historia y crítica de la opinión pública, Barcelona, Gustavo Gili.

Jara Fuente, José Antonio (20II): «Por el conosçimiento que de él se ha’. Identificar, designar, atribuir la construcción de identidades (políticas) en Cuenca en el siglo XV», Hispania: Revista Española de Historia, vol. 7I, n. 238, pp. $389-408$

Jara Fuente, José Antonio (20I3A): «Identidad política urbana: una reflexión sobre las políticas comunitarias y las identidades comunitarias en la Castilla urbana del siglo xv», en José Antonio Jara Fuente (coord.), Ante su identidad: la ciudad hispánica en la Baja Edad Media, Cuenca, Universidad de Castilla-La Mancha, pp. 93116
Jara Fuente, José Antonio (20I3B): «Didáctica de las relaciones políticas ciudad-nobleza en la Cuenca del siglo xv: "Çercada de muchos contrarios"”, Edad Media: revista de historia, n. I4, 2013b, pp. I05127.

Jara Fuente, José Antonio (COORd.) (20I7): Discurso politico y relaciones de poder: ciudad, nobleza y monarquia en la Baja Edad Media, Madrid, Dykinson.

Kagan, Richard L. (20I0): Los cronistas y la Corona: la politica de la histora en España en las edades media y moderna, Madrid, Centro de Estudios Europa Hispánica, Marcial Pons.

López Alonso, Covadonga (20I4): Análisis del discurso, Madrid, Síntesis.

MACKay, Angus (1985): «Ritual and propaganda in fifteenth-century Castile», Past \& Present, n. I07, pp. 3-43.

Mairey, Aude (2009): «Les langages politiques au Moyen Âge (XII ${ }^{e}-\mathrm{XV}^{\mathrm{e}}$ siècle), Médiévales. Langues, Textes, Histoire, n. 57, pp. 5-I4.

Maisonneuve, Jean (2017): La psycologie sociale, Paris, Presses Universitaires de France.

Manuel de Lando, Ferrán (1989), "En el torneo Campal», en Rodríguez Puértolas, Julio, Poesía crítica y satírica del siglo xv, Madrid, Castalia, pr. 82-90

Meersohn, Cynthia (2005): «Introducción a Teun van Dijk: Análisis de discurso", Cinta de Moebio, n. 24, pp. 288-302.

Mexía, Pedro (1945): Historia del Emperador Carlos V, edición de Juan de Mata Carriazo, Madrid: Espasa-Calpe.

Monsalvo Antón, José María (2OII): «Ideario sociopolítico y valores estamentales de los pecheros abulenses y salmantinos (ss. XIII-Xv)», Hispania: Revista Española de Historia, vol. 71, n. 238, pp. 325-362.

Monsalvo Antón, José María (2016): Los conflictos sociales en la Edad Media, Madrid, Síntesis.

Monsalvo Antón, José María (2019A): La construcción del poder real en la Monarquia castellana (siglos XI-XV), Madrid, Marcial Pons Historia.

Monsalvo Antón, José María (ED.) (2019B): Élites, conflictos y discursos politicos en las ciudades bajomedievales de la Península Ibérica, Salamanca, Universidad de Salamanca, 2orgb.

Montero Málaga, Alicia Inés (2013): «Dos cronistas para un reinado: Alonso de Palencia y Diego Enríquez del Castillo», Estudios medievales hispánicos, n. 2, pp. 107-I28.

Nieto Soria, José Manuel (1988): Fundamentos ideológicos del poder real en Castilla (siglos XIII-XVI), Madrid, EUDEMA.

Nieto Soria, JosÉ Manuel (1999): «La realeza», en José Manuel Nieto Soria (dir.), Origenes de la monarquia hispánica: propaganda y legitimación (ca. I400-I520), Madrid, Dykinson, pp. 25-62.

Nieto Soria, José Manuel (2004): «La parole: un instrument de la lutte politique dans la Castille de la fin du Moyen Âge», Revue historique, vol. 4, n. 632, pp. 707-725.

Nieto Soria, José Manuel (2005): “Rex inutilis’ y tiranía en el debate político de la Castilla bajomedieval», en Foronda, François, Genet, JeanPhilippe y Nieto Soria, José Manuel (eds.), Coups d'état à la fin du Moyen Âge? Aux fondements du pouvoir politique en Europe occidentale, Madrid, Casa de Velázquez, pp. 73-92

Nieto Soria, José Manuel (2007): «La propaganda política de la Teocracia Pontificia a las Monarquías Soberanas», en José Manuel Nieto Soria, et al., Propaganda y opinión pública en la historia, Valladolid, Universidad de Valladolid, pp. II-47.

Nieto Soria, José Manuel (20I7): «Álvaro de Luna as Tyrant. Public Opinion and Political Conflict in I5th century Castile», Imago Temporis: Medium Aevum, vol. II, pp. 273-297. 
Nogales Rincón, David (20II): «Animalización, sátira y propaganda real: la metáfora y la alegoría animal como instrumento político en la Castilla bajomedieval (siglos xiv-xv)", Signum, vol. II, n. I, pp. 267-296.

Oliva Herrer, Hipólito Rafael (20iI): “La prisión del rey’” voces subalternas e indicios de la existencia de una identidad política en la Castilla del siglo XV", Hispania: Revista Española de Historia, vol. 71, n 238, pp. 363-388.

Oliva Herrer, Hipólito Rafael, Challet, Vincent, Dumolyn, Jan, Carmona Ruiz, María Antonia (Dirs.) (20I4): La comunidad medieval como esfera pública, Sevilla, Universidad de Sevilla.

Ortega Sierra, Sara (20I7): «La emergencia de la subjetividad literaria en los dezires y la evolución de la lírica tardomedieval", Lemir: Revista de Literatura Española Medieval y del Renacimiento, n. 2I, pp. 291-312.

Martín Romero, José Julio (2013): La "Batalla campal de los perros contra los lobos». Una fábula moral de Alfonso de Palencia, San Millán de la Cogolla, Cilengua.

Perea Rodríguez, Óscar (2007): «El entorno cortesano de la Castilla Trastámara como escenario de lucha de poder. Rastros y reflejos en los cancioneros castellanos del siglo xV», Res publica: revista de filosofía politica, n. 18, pp. 289-306.

Pérez de Guzmán, Fernán (1998): Generaciones y semblanzas, edición de José Antonio Barrio Sánchez, Madrid, Cátedra.

Pérez de Tudela Velasco, Ma Isabel (20II): «El ejército cristiano en la España altomedieval: de la derrota militar ante los musulmanes, a la resistencia espontánea frente a ellos», En la España Medieval, vol. 34, pp. 9-24.

Pontón, Gonzalo (2008): «Fernando de Pulgar y la "Crónica de los Reyes Católicos"», en Fernando de Pulgar, Crónica de Los Reyes Católicos, edición de Juan de Mata Carriazo, Granada, Editorial Universidad de Granada.

Pulgar, Fernando de (1943): Crónica de Los Reyes Católicos, edición de Juan de Mata Carriazo, Madrid, Espasa Calpe.

Quintanilla Raso, María Concepción (2005): «Discurso aristocrático, resistencia y conflictividad en el siglo xv castellano», en Foronda, François, Genet, Jean-Philippe y Nieto Soria, José Manuel (eds.), Coups d'état à la fin du Moyen Âge? Aux fondements du pouvoir politique en Europe occidentale, Madrid, Casa de Velázquez, pp. 543-573.

Rodríguez de las Heras, Antonio (198I): «Las regulaciones del conflicto», Norba. Revista de Historia, n. 2, pp. 273280.

Rodríguez Puértolas, Julio (I968): Poesía de protesta en la Edad Media castellana, Madrid, Gredos.
Rodríguez Puértolas, Julio (1989): Poesía crítica y satírica del siglo XV, Madrid, Castalia.

Rosenwein, Barbara H. (2006): Emotional Communities in the Early Middle Ages, Ithaca, Cornell University Press.

Rucquol, Adeline (COORD.) (1988): Realidad e imágenes del poder: España a fines de la Edad Media, Valladolid, Ámbito.

Rucquoi, Adeline (2006): "Ser noble en España (siglos xiv-Xvi)", en Rucquoi, Adeline (ed.), Rex, sapientia, nobilitas, Granada, Universidad de Granada, pp. 2II-248.

Scholberg, Kenneth R. (1971): Sátira e invectiva en la España medieval, Madrid, Gredos.

Serverat, Vincent (1997), LA POURPRE ET LA GLĖBE: rhétorique des états de la société dans l'Espagne médiévale, Grenoble, ELLUG.

Severin, Dorothy (2005): «Política y poesía en la corte de Isabel la Católica», en Piñero Ramírez, Pedro Manuel (coord.), Dejar hablar a los textos: Homenaje a Francisco Márquez Villanueva, Sevilla, Universidad de Sevilla, vol. I, pp. 239-250.

Tabernero, Cristina, Usunáriz, Jesús M. (2019): Diccionario de injurias de los siglos XVI y XVII, Kassel, Reichenberger.

VALdeÓN, Julio (1992): «La propaganda ideológica, arma de combate de Enrique de Trastámara (1366-1369)», Historia. Instituciones. Documentos, n. 19, pp. 459-468.

VALDEÓN, Julio (1983): Los conflictos sociales en el reino de Castilla en los siglos XIV $y$ XV, Madrid, Siglo XXI.

Valera, Diego de (1959): «Espejo de verdadera nobleza», en Mario Penna (ed.), Prosistas castellanos del siglo XV, Madrid, Atlas, 1959.

Valera, Diego de (1927): Crónica de los Reyes Católicos, edición de Juan de Mata Carriazo, Madrid, Centro de Estudios Históricos.

VALERA, Diego de (194I), MeMORIAL DE DIVERSAS HAZANAAS: crónica de Enrique $I V$, edición de Juan de Mata Carriazo, Madrid, Espasa-Calpe.

Van Dijk, Teun A. (2012): Discurso y contexto: un enfoque sociocognitivo, Barcelona, Gedisa.

Van Dijk, Teun A. (2009): Discurso y poder: contribuciones a los estudios críticos del discurso, Madrid, Gedisa.

Van Dijк, Teun A. (2003): Ideología y discurso: una introducción multidisciplinaria, Barcelona, Ariel.

Villa Prieto, Josué (20I5), «La escritura de la Historia en la Baja EDAD MEDIA: deseo racional versus propaganda política. La mentalidad de los cronistas», Historiografias: Revista de Historia y Teoría, n. I0, pp. 6584. 
